\title{
New geographical Record of the Blue-dashed Rockskipper, Blenniella periophthalmus (Valenciennes, 1836) from the Saint Martin's Island of Bangladesh
}

\author{
Kazi Ahsan Habib1*, Amit Kumer Neogi², Jayedul Islam² and \\ Najmun Nahar ${ }^{2}$ \\ ${ }^{1}$ Department of Fisheries Biology and Genetics, Faculty of Fisheries, Aquaculture and \\ Marine Science, Sher-e-Bangla Agricultural University, Bangladesh \\ ${ }^{2}$ Aquatic Bioresource Research Lab, Department of Fisheries Biology and Genetics, \\ Sher-e-Bangla Agricultural University, Bangladesh
}

*Corresponding author: Kazi Ahsan Habib, Department of Fisheries Biology and Genetics, Faculty of Fisheries, Aquaculture and Marine Science, Sher-e-Bangla Agricultural University, Dhaka 1207, Bangladesh, Tel: +880-1713682290; Email: ahsan.sau@gmail.com

The family Blenniidae comprises 58 genera and 397 species [1]. They are of small benthic fishes inhabit shallow, inshore, often intertidal, waters. The habitats of blennies range from rocky pools to sandy beaches, reefs, and beds of kelp. Blennies are generally benthic, occupying grass beds, tide pools, or areas near rocks, shells, or corals [2]. The genus Blenniella Reid, 1943, in the family Blenniidae, comprises 9 valid species over the world, that extend five species of genus Blenniella have recorded in Eastern India Ocean viz. Blenniella leopardus, Blenniella periophthalmus Valenciennes, 1836; Blenniella chrysospilos Bleeker, 1857; Blenniella cyanostigma Bleeker, 1849; and Blenniella gibbifrons Quoy \& Gaimard, 1824 [3].

Blenniella periophthalmus is a species commonly known as Blue-dashed rockskipper found in coral reef habitats. B. periophthalmus is an exclusively marine fish and also reef-associated species that occurs in tropical climates with a depth range of 0-3 $\mathrm{m}$ [4].

We herein report the first record of occurrence $B$. periophthalmus from the Saint Martin's Island of Bay of Bengal located at southern tip of Bangladesh (Figure 1). A group of specimens were observed during underwater fish survey at the floor of rocky reef habitat on 11
November 2017 (GPS coordinate between $20.611^{\circ} \mathrm{N}$ $92.327^{\circ} \mathrm{E}$ ). This species inhabits exposed outer intertidal reef flats, where it can hide in cracks and holes. It is commonly observed clinging to rocks as the water recedes below them during the low cycle of the swell and this species is often confused with mudskipper gobies [5].

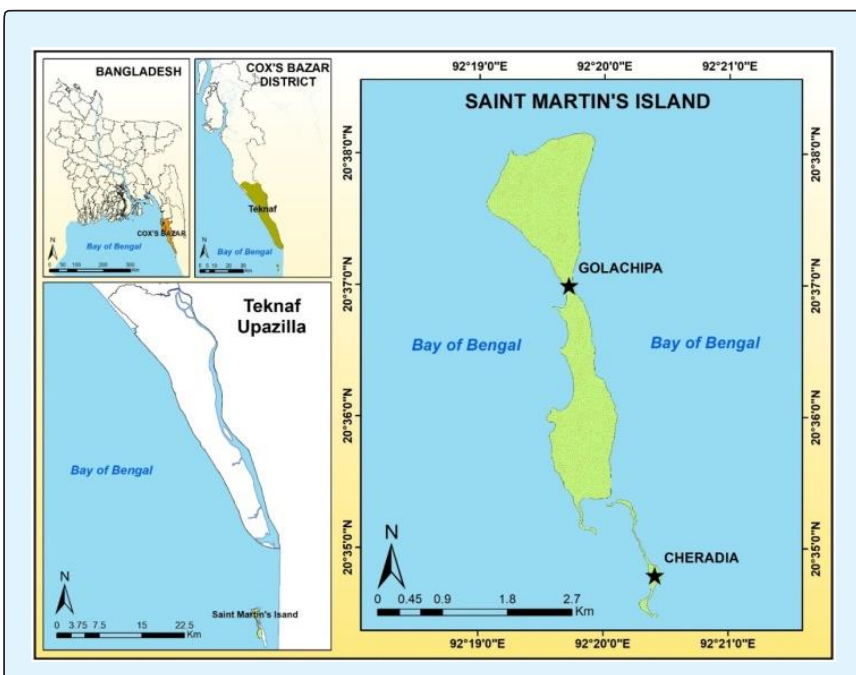

Figure 1: Map of Saint Martin's Island located tip of the Bay of Bengal, Bangladesh. 


\section{Journal of Ecology \& Natural Resources}

\section{Diagnosis}

Color variables for different localities. Body of males with 6-7 dusky bands with 1 or a pair of dark margined, pale, oblong spots on each band; dark spots on spinous dorsal, dusky lines on rayed dorsal (Figure 2). Females with spots on caudal peduncle; body sometimes with fine dark specks. Body naked. Fleshy blade-like crest present on top of head of male. 0 to 7 bi-pored lateral-line tubes present. Apparent segmented pelvic-fin rays 3; segmented dorsal-fin rays more than 17; nape cirri present or absent. Canine teeth present posteriorly on dentary; no teeth on vomer. Orbital cirrus a simple filament, occasionally with 1 or 2 side branches, or filament with several fine branches at tip.

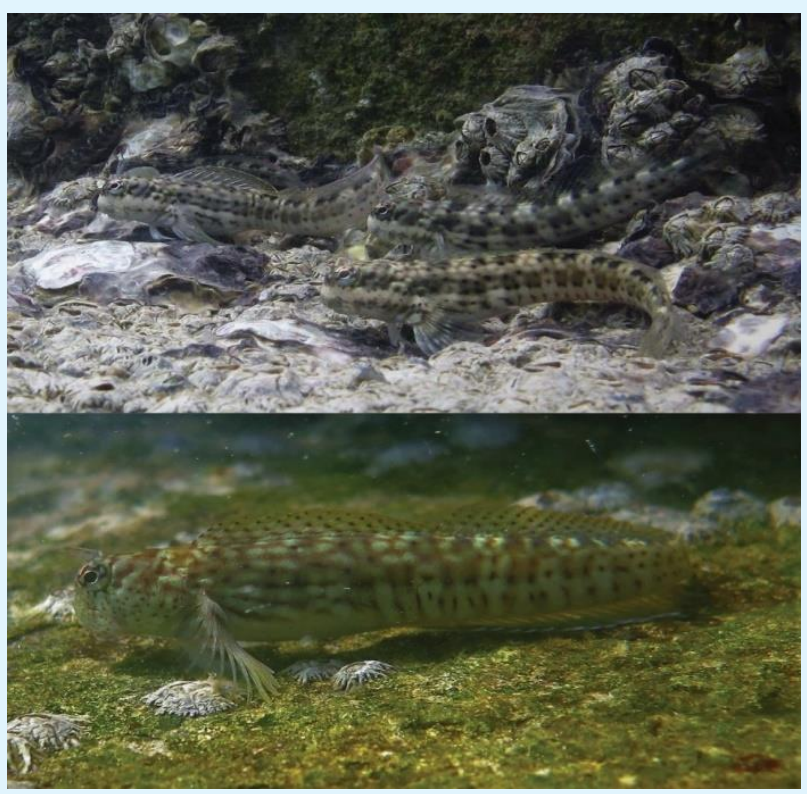

Figure 2: Images of Blenniella periophthalmus observed during underwater fish survey in the floor of rocky reef habitat at St. martin`s Island; 11.XI.2017; GPS coordinate $20.611^{\circ} \mathrm{N} 92.327^{\circ} \mathrm{E}$.

\section{Distribution}

The Blue-dashed rockskipper, B. periophthalmus has a wide distribution range and it is found in the Indo-Pacific and Western Central Pacific oceans [6], India, Andaman and Nicobar islands, Indonesia, Maldives [7].

By now, two species of Blennies, Petroscirtes breviceps (Valenciennes, 1836) and Istiblennius dussumieri
(Valenciennes, 1836) have been recorded from the Bangladesh waters $[8,9]$. Therefore, this present note confirmed the existence of B. periophthalmus in the Saint Martin's Island, Bay of Bengal and indicates the possibility of existence of more species in the family Blenniidae in Bangladesh waters that have been overlooked in past surveys.

\section{Acknowledgements}

This research has been carried out under the CRG subproject using the research grant of USAID Trust Fund and Government of Bangladesh through Ministry of Agriculture. We would like to thanks to the World Bank for arranging the grand fund. We acknowledge to Mr. Sufi Md Atiqur Rahman and Mr. Sharif Sarwar two professional underwater photographer for their help to this under water exploration.

\section{References}

1. Nelson JS (2006) Fishes of the World. $4^{\text {th }}$ (Edn.), Hoboken (New Jersey, USA): John Wiley \& Sons, pp: 601.

2. Springer V (1994) Blennies. In: Eschmeyer W, Paxton J (Eds.), Encyclopedia of Fishes-second edition. San Diego, CA: Academic Press, Pp: 214-217.

3. Froese R, Pauly D (2019) Fish Base.

4. Allen GR, Steene RC (1988) Fishes of Christmas Island Indian Ocean. Christmas Island Natural History Association, Christmas Island, Indian Ocean, 6798, Australia, Pp: 197.

5. Ketabi R, Jamili S (2017) Blenniella periophthalmus (Valenciennes, 1836). Iran, Kish International Campus, Tehran University.

6. Kami HT (1971) Check-list of Guam fishes, supplement I. Micronesica 7(1-2): 215-228.

7. Rajan PT, Sreeraj CR, Immanuel T (2011) Fish fauna of coral reef, mangrove, freshwater, offshore and seagrass beds of Andaman and Nicobar Islands. Zoological Survey of India, Andaman and Nicobar Regional Centre, Haddo, Port Blair.

8. Rahman AKA, Kabir SMH, Ahmad M, Ahmed ATA, Ahmed ZU, et al. (2009) Encyclopedia of Flora and Fauna of Bangladesh. Marine Fishes. Asiatic Society of Bangladesh, Dhaka, 24: 485. 


\section{Journal of Ecology \& Natural Resources}

9. Akash M, Sultana MN, Palash A, Jahan N (2018) On surveying the rocky tidal habitats of St Martin's Island: Bangladesh gets nine new species, eight new genera and two new families. The $21^{\text {st }}$ National Conference, Zoological Society of Bangladesh, Dhaka, Bangladesh, pp: 122. 